\author{
О.О. Головін ${ }^{1}$, М.А. Попова ${ }^{2}$, К.Г. Яценко ${ }^{3}$ \\ ${ }^{1}$ Центральний науково-дослідний інститут озброєння та військової техніки \\ Збройних Сил Украӥни, Київ \\ ${ }^{2}$ Національний центр “Мала академія наук Украӥни”, Київ \\ ${ }^{3}$ Харківський національний університет Повітряних Сил ім. І. Кожедуба, Харків
}

\title{
ОНТОЛОГІЧНІ ЗАСАДИ ВЗАЄМОДІЇ ЕКСПЕРТІВ 3 ІНФОРМАЦІЙНО-АНАЛІТИЧНОЮ СИСТЕМОЮ ПІДТРИМКИ ПРИЙНЯТТЯ РІШЕНЬ 3 РОЗВИТКУ ОЗБРОЄННЯ ТА ВІЙСЬКОВОЇ ТЕХНІКИ
}

Рімення проблеми семантичної гетерогенності даних в перспективній інформаційно-аналітичній системі підтримки прийняття рішень з розвитку ОВТ здійснюється за рахунок використання інструментарію онтологій шляхом формування з вхідної інформації уніфікованого інформачійно-понятійного простору. Використання методів аналізу природно-мовних об'єктів та класичної логіки першого порядку дозволяє здійснити поєднання формального представлення семантики з інформаційними масивами, які складають основу наративу всієї вхідної інформачії про опис зразків ОВТ.

Ключові слова: інформаційно-аналітична система, онтологія, предметна область, онтологічний інтерфейс, наратив інформачійних ресурсів.

\section{Вступ}

Постановка проблеми. Діяльність експертів в галузі розвитку озброєння та військової техніки (OBT) пов'язана 3 аналізом перманентно зростаючих потоків тематично та просторово розподіленої, слабко структурованої або неструктурованої інформації. Потреба іiі якісної обробки, інтуїтивно зрозумілого, багатоаспектного представлення даних вимагають створення методів та засобів взаємодії експертів $з$ інформаційними ресурсами для забезпечення їх ефективного використання.

Оскільки вхідна інформація в галузі розвитку OВТ має слабоформалізований вигляд, розробка традиційних математичних моделей для її обробки $\epsilon$ складною та вимагає значних витрат, що перевищують очікуваний ефект зазначеної обробки. Зазвичай завдання дослідження внутрішніх взаємодій в інформаційно-аналітичній системі (IAC), факторів впливу, динаміки предметної області (ПдО), враховуючи неповноту або неточність описів об'єктів, вирішуються на неформальному рівні експертамифахівцями. Для підтримки їх взаємодії між собою та 3 інформаційними ресурсами виникає питання формування 3 вхідної інформації уніфікованого інформаційно-понятійного простору на основі онтології.

Аналіз останніх досліджень і публікацій. Дослідженню даного напрямку присвячені роботи [16]. Однак проблеми онтологічної взаємодії експертів з IAC в галузі розвитку ОВТ на даний час лишаються не вирішеними.

Мета статті полягає у розробці підходів до формування онтологічного інтерфейсу IАC підтри- мки прийняття рішень 3 розвитку ОВТ (IAC ППР ОВТ) та реалізації його функцій.

\section{Виклад основного матеріалу}

Будучи аналогом поняття “модель”, онтологія слугує засобом комунікації між користувачами, ресурсами та системами завдяки поєднанню інформаційних описів на основі об'єктно-орієнтованої процедури формалізації 3 описами інтерпретаційних функцій, які керують процесом постачання інформаційного ресурсу, а ії формальна структура спрощує комп’ютерну обробку та дозволяє відобразити специфічні завдання інформаційного середовища. Використання онтології ефективне й при агрегації інформації з різних джерел і середовищ, ії представленні та інтерпретації в процесі вирішення задач [7-8].

Онтологічний підхід забезпечує технологічну організацію вирішення проблем взаємодії з розподіленими інформаційними ресурсами за рахунок наявності таких факторів:

множина організаційно і фізично розподілених користувачів одночасно взаємодіє із загальнодоступними даними (користувачі розташовані за різними робочими місцями з різними повноваженнями і завданнями);

логічно і фізично розподілені дані утворюють єдине взаємоузгоджене ціле - єдиний інформаційний простір (окремі таблиці, записи і навіть поля можуть розташовуватися на різних робочих місцях, або належати до різних локальних баз даних).

3 метою забезпечення ефективної спільної взаємодії користувачів 3 інформаційними ресурсами, що використовуються для прийняття рішень в галузі 
розвитку ОВТ, необхідно вирішити комплекс технічних проблем. Основною проблемою є проблема об'єднання гетерогенних і розподілених комп'ютерних систем (проблема інтероперабельності (interoperability problem)). Інтероперабельність (здатність системи, інтерфейс якої повністю відкритий, взаємодіяти і функціонувати з іншими системами без будь-яких обмежень доступу і реалізації) потрібно забезпечувати і на технічному, і на інформаційному рівні [9]. Проблеми, що могли б виникати внаслідок гетерогенності даних, вже відомі в межах співтовариства розподілених систем баз даних [10]:

структурна гетерогенність (схематична гетерогенність) - різні інформаційні системи зберігають свої дані в різних структурах;

семантична гетерогенність (гетерогенність даних) розглядає зміст інформаційного елемента.

3 метою досягнення семантичної інтероперабельності в гетерогенній інформаційній системі, зміст інформації, якою обмінюються користувачі, має бути зрозумілим у всіх системах. Використання онтологій для пояснення неявного і схованого знання можливий підхід вирішення проблеми семантичної гетерогенності [9].

Сказане вище і ряд інших факторів свідчать про доцільність застосування парадигми комп'ютерних онтологій, основними принципами якої є такі [4]:

1. Дохідливість, ясність (Clarity). Терміни (поняття) онтології повинні відображати реальну дійсність, а їх символьні позначення (знаки) - формуватися на основі загальноприйнятих правил в семіотиці і висловлювати загальноприйнятий зміст реальних об'єктів. В свою чергу, ці змісти вилучаються із загальноприйнятих визначень термінів (понять), зафіксованих в тлумачних словниках, різних глосаріях предметної області. Судження, що входять до визначення, формалізуються на основі формального загальноприйнятого апарату у вигляді істинних логічних аксіом.

\begin{tabular}{l}
$\begin{array}{l}\text { За ступенем формальності: } \\
\text { неформальні; } \\
\text { напівформальні; } \\
\text { формальні }\end{array}$ \\
\begin{tabular}{|l|} 
Представлення онтології \\
не представлена; \\
списки; \\
графічно; \\
вербально; \\
вихідний код
\end{tabular} \\
\hline
\end{tabular}

Рис. 1. Схема реалізації принципів побудови онтолого-вдосконаленого інтерфейсу
2. Обгрунтованість, зв'язність (Coherency). Формування початкового набору понять онтології i їх додатків має бути обгрунтованим та відповідати, в першу чергу, вимогам передбачуваної сукупності розв'язуваних задач. Логічні аксіоми початкового набору понять повинні бути несуперечливими, для чого має бути передбачений механізм логічного виведення, який, в тому числі, перевіряє на несуперечність аксіоми, які додаються і виведені в онтології твердження

3. Розиирюваність (Extendibility). Ядром онтології є спочатку введені (спроектовані) поняття i аксіоми, що їх описують. В онтології повинен бути передбачений механізм розширення/обмеження спільно використовуваних словників понять без порушення цілісності системи.

4. Мінімальний вплив кодування (Minimal encoding bias). В онтологічній системі повинен бути реалізований принцип спільного використання онтологій, який передбачає: специфікацію онтології на рівні повноцінного представлення, а не символьного кодування. Запис такої специфікації загальноприйнятою та платформонезалежною мовою опису онтологій можна передати для використання будь-якому програмному агенту.

5. Мінімальні онтологічні зобов'язання (Minimal ontological commitment). Цей принцип перекликається з принципами обгрунтованості та розширюваності/обмеження. Важливо, щоб множина понять онтології відображала концептуальну структуру предметної області, відносно стабільну протягом “життєвого циклу” онтологічної системи, а остання надавала б можливість розширення або спеціалізації окремих гілок онтологічного графа. Відділення концептуальних знань від знань, виражених фактами, є стратегією побудови онтологічної системи, а точніше - онтологічних баз знань.

На підставі зазначеного, схему реалізації принципів побудови онтолого-вдосконаленого інтерфейсу наведено на рис. 1. 
Так, онтологія користувачів та їх функцій характеризує користувачів, їх уподобання, функції та/або права і можливості, які вони мають в процесі використання системи.

Онтології, що охоплюють більш, ніж одну 3 цих ПдО, можуть бути використані в одній системі, адже технічно можливо змішати різні області в одній онтології. Проте, доцільно відокремити їх в різні онтологічні модулі з міркувань розподілу навантаження та гнучкості при повторному використанні онтології [11].

Уніфікація змісту, під якою розуміється однозначна інтерпретація вхідної інформації у інформаційно-аналітичному середовищі, забезпечується розробкою онтологій, які можуть стати універсальним апаратом для вирішення різноманітних специфічних завдань в різних проблемних областях, що обумовлюється спроможністю розв'язання багатьох нестандартних завдань стандартним способом в онтографах. Також важливим є те, що за допомогою одного онтологічного графу можна вирішувати кілька різних завдань без необхідності створення спеціалізованих додатків для кожної специфічної задачі. Застосування онтологій дозволяє створити адекватні концептуальні моделі, забезпечуючи якісне, контрольоване інформаційне інтегрування та здійснити поєднання формального представлення семантики, закладеної в онтологіях з інформаційними масивами, які складають основу наративу усієї вхідної інформації щодо описів ОВТ.

Вирішення задачі проблемної ситуації здійснюється шляхом взаємодії експерта 3 частинами онтології ПдО, наслідуючими всі властивості та відношення загальної онтології, що представляється послідовністю іiі актуалізованих при досягненні цілей станів в інформаційному середовищі.

Під взаємодією частин онтології будемо розуміти утворення непорожнього твердження, яке пов'язує компоненти онтології певною дією - перетворенням концептів (встановлення, формулювання та/або доведення істинності утвореного концептами висловлювання, визначення типу відношень між ними тощо), тобто взаємодія передбачає участь у формуванні стану досягнення цілі щонайменше двох компонентів онтології, які здійснюють одна на одну певний вплив, наприклад, утворюють предикативні висловлювання або істинні твердження.

Процес вирішення задачі являє собою певну послідовність упорядкованих тавтологій, кожна 3 яких наслідує усі властивості концептів тавтології, що їй безпосередньо передує.

Процес вирішення проблемної задачі починається, перш за все, з фіксації певної частини об’єктивної реальності - ПдО з наступною побудовою іiі узагальненої моделі. На цьому етапі необхідним $є$ виявлення найбільш істотних рис, явищ ПдО, визначення елементарних понять та їх взаємозв'язків, аксіом і обмежень, керуючих розвитком даної ПдО, тобто створення деякого образу реальності, що відображає “нестроге” суб'єктивне іiї сприйняття особою, що вирішує задачу. Для фіксації добутих знань необхідно визначити відповідний формалізм, що забезпечує їх наочне і зручне подання, та який включає власну мову, за можливості більш строгу, ніж природна, і в той же час не дуже відмінну за сприйняттям від останньої, а також методи, що дозволяють здійснити цю формалізацію. В якості такого формалізму виступає сполучення алгебрологічного та аксіоматичного методів.

Наступний етап полягає в побудові формальної теорії представлення ПдО задачі, а саме кожному виразу теорії (поняттю ПдО) необхідно співставити конкретний об'єкт, а кожному судженню - зв'язки між поняттями відповідних реальних об'єктів, які входять до складу даного судження. Після цього можна визначити істинність або хибність висловлювань теорії, тобто судити про правильність міркувань ПдО. Далі здійснюється дослідження побудованої моделі в строгому науковому сенсі: висуваються вимоги до їі повноти, несуперечливості, простежується іiї еволюція i, нарешті, інтерпретуються отримані знання із заданої ПдО.

Невід'ємною компонентою ІАС ППР ОВТ на основі онтології є база знань, в якій у формалізованому вигляді представлені знання про предметну область. Саме наявність цих знань дозволяє успішно вирішувати як традиційні, так і нові проблемні задачі в галузі розвитку ОВТ, які раніше були винятково прерогативою наукової творчості. Представлені в онтології знання одночасно можуть виступати як інформаційна структура концептуальних знань ПдО, так і як змістове наповнення інформаційної системи.

Таким чином, методологія побудови IАC ППР OBТ представляється на основі комплексного набору методів аналізу природно-мовних об'єктів, класичної логіки першого порядку для їх формальнологічного представлення, структуризації онтологічних знань, процедур прикладного процесингу та відповідних архітектур IAC на основі онтології, а також вибору відповідної пари <метод - архітектура> для вирішення конкретного набору типових проблемних задач в галузі розвитку ОВТ.

Таке понятійне середовище взаємодії користувачів IAC ППР ОВТ розглядається як велика онтолого-керована система, яка представляє природномовні об'єкти (ПМО) [12] як елементи загальної природно-мовної картини 3 відповідними взаємопов'язаними ПдО, що описуються онтологіями (рис. 2). При вирішенні задачі необхідним є визначення об'єкту дослідження, який може бути ПдО, іiі тематичним розділом, об'єктами, процесами, явищами, функціональним описом і може мати стан, 
структуру, властивості, межі, виявляти чітку функціональність. Група чи множина об'єктів, що мають зв'язки та пов'язані спільною структурою та функціональністю, можуть бути об'єднані в класи. Описані ПдО визначаються поставленими завданнями про контент-аналіз, результати якого використову- ватимуться при вирішенні задачі. Онтологічний інтерфейс забезпечує для користувачів відображення складових об'єктів та їх властивостей, як при зборі даних, їх аналізі, так і при взаємодії агентів (систем, користувачів).

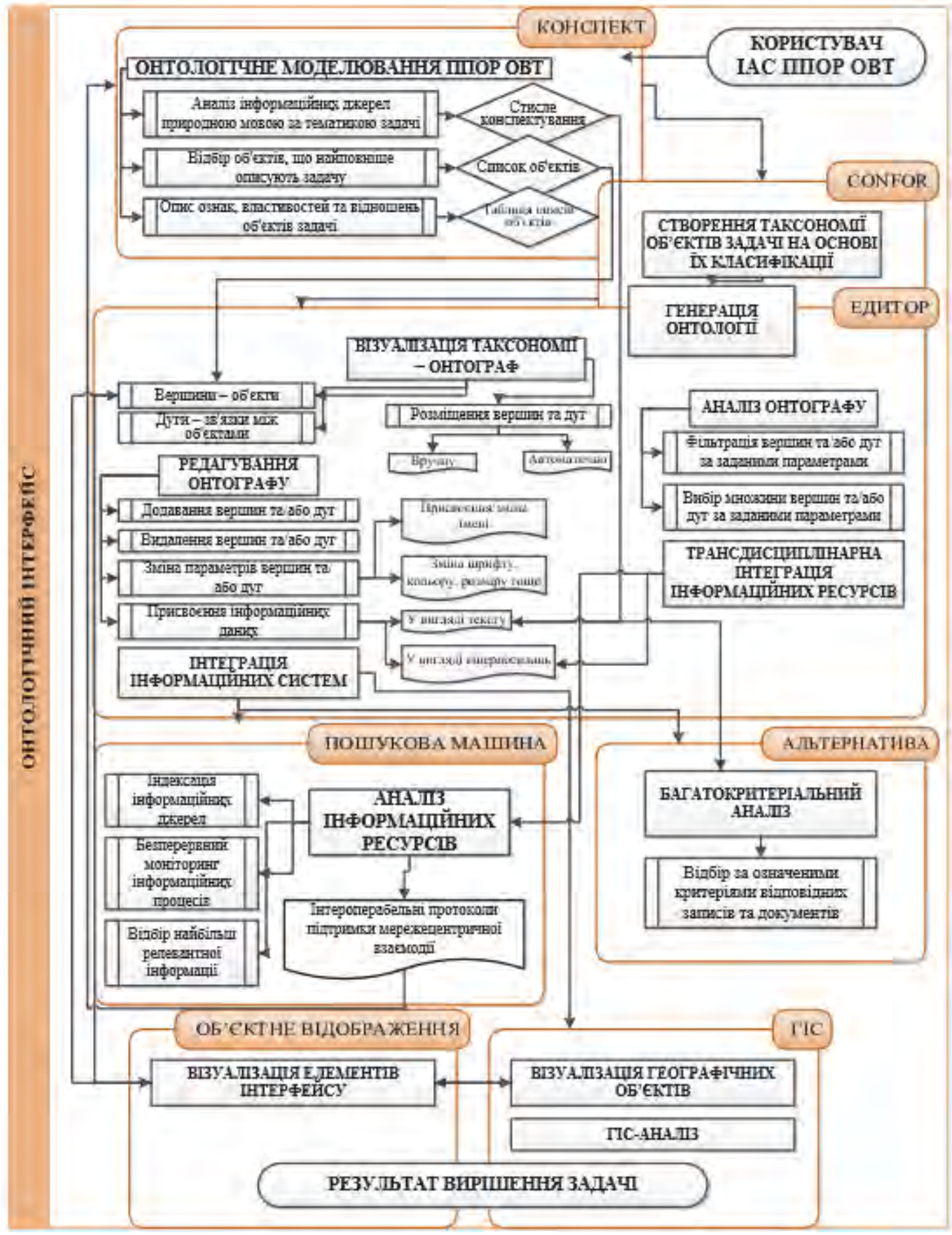

Рис. 2. Схема побудови онтологічного інтерфейсу

Онтологічний інтерфейс - засіб зручної взаємодії користувача 3 IAC, призначений для розв'язання множини задач проблемної ситуації шляхом використання тематичної онтології. Онтологічний інтерфейс дозволяє візуалізувати результат процесів інтеграції та агрегації фізично та тематично розподілених інформаційних ресурсів та систем, створених у різних форматах, за різними стандартами та технологіями, у легкодоступній наочній формі. На відміну від інформації, закодованої в алгори- 
тмах, тематична онтологія, яка є системою логічних тверджень дескриптивної логіки, забезпечує іiі уніфіковане і багаторазове використання різними групами користувачів на різних комп'ютерних платформах під час розв'язання різних задач.

Одним із завдань ІАС ППР ОВТ, що проектується, є вирішення задач концептуального відображення взаємодії інформаційних процесів в різних предметних областях технічного оснащення 3С України, що досягається за рахунок:

відображення множини концептів як топологічної структури семантичних одиниць-понять;

представлення формальної моделі предметних знань певною мовою на основі опису концептуальної системи;

функціонального моделювання, яке забезпечує уніфікацію термінології, логіки обробки таксономічних категорій і відношень між ними, а також аксіоматизацію описів процесів, процедур та причинних зв'язків.

Відповідно, в основу реалізації користувальницького інтерфейсу покладено онтологічний підхід до управління корпоративними знаннями, завдяки якому забезпечуються їх використання в процесах управління та визначення найкращих стратегій оптимізації діяльності органів військового управління та установ, що задіяні до процесів створення (модернізаціі) ОВТ.

Онтології працюють як 3 формальними, так i неформальними знаннями, що дозволяє генерувати нові знання та підвищити ефективність функціонування системи розробки та постановки на виробництво ОВТ за рахунок їх обміну, пошуку, уточнення, зберігання, передачі та використання.

3 метою впорядкування та управління великою кількістю різноформатних даних, як 3 власних баз даних, так і з інтегрованих джерел, пропонується використання онтологічного інтерфейсу, що поєднує принципи онтологічного управління знаннями 3 концепцію Semantic Web. Перехід від незалежних один від одного документів до концепції семантично пов'язаних інтерактивних онтологічних документів дозволяє розширювати тезаурус онтології термінами з інших джерел, не вимагаючи при цьому реструктуризації онтології.

До того ж, інтерактивні онтологічні документи можуть інтегрувати декілька онтологій різних ПдО для формування єдиного трансдисциплінарного інформаційного простору, що скорочує часові та фінансові витрати на реалізацію ІАС ППР ОВТ.

В процесі додавання в онтологію нових знань 3 часом з'являється проблема іiї розуміння, у вирішенні якої велику роль відіграє візуалізація. При цьому необхідно врахувати психологічні особливості сприйняття і структурування людиною інформації.
Онтологічний інтерфейс забезпечує інтегроване сприйняття інформації завдяки доступу до агрегованих розподілених мережевих інформаційних ресурсів в єдиній багатофункціональній онтологокерованій ІАС ППР ОВТ. Ефективність використання інформації підвищується за рахунок своєчасності іiі отримання, корисності, доцільного дозування, доступності (зрозумілості), мінімізації шуму, оперативного взаємозв'язку джерела інформації та користувача, адаптації темпу подання інформації до швидкості іiі засвоєння, врахування індивідуальних особливостей користувача тощо.

Онтологічний інтерфейс не потребує перегенерування коду за будь-якої зміни в структурі тематичної онтології та не вимагає спеціалізованих знань та навичок програмування від користувача. На основі засобів Semantic Web онтологічний інтерфейс адаптується під тематичний профіль кожного окремого суб'єкта інформаційно-аналітичної діяльності, забезпечуючи відображення складових об'єктів та їх властивостей як при зборі даних, їх аналізі, так і при взаємодії агентів (систем, користувачів) в процесі вирішення задач.

Онтологічний інтерфейс розширює традиційні функції онтології та перетворює іiі на динамічне середовище активної взаємодії користувачів з інформаційними ресурсами IAC ППР ОВТ шляхом інтеграції з різноманітними базами даних, пошуковими платформами, електронними бібліотеками та мовними корпусами, іншими інформаційними системами для підвищення ефективності та прискорення процесу вирішення задач.

Формування онтологічного інтерфейсу полягає в автоматичній генерації коду за моделлю онтологічного графа (таксономіі), тобто, у співставленні об'єктів тематичної онтології набору вихідних кодів мовою програмування. Зміна таксономії (структури онтологіi) не вимагає внесення змін до коду інтерфейсу, що забезпечує динамічну розширюваність, адже описує відповідності між компонентами онтології та інструкціями цільової мови програмування.

Таким чином, генератор коду інтерфейсу керується моделлю онтології, яка реалізується у вигляді широкого набору програмних компонентів і складається зі статичної та динамічної частин. Статична частина містить шаблони файлів, що реалізують фіксовані алгоритми для управління процесом генерації коду, а динамічна частина містить алгоритми відображення описів компонентів моделі інтерфейсу на програмний код (інструкції мови програмування).

Елементами онтологічного інтерфейсу $є$ інформаційне наповнення тематичної онтології. Візуальним відображенням об’єкта онтології є зображення (рисунок, картинка, іконка, фотографія тощо), джерело знаходження якого вказано у відповідній вершині онтографа (таксономіі). Порядок об’єктного 
відображення (у вигляді галереї зображень) понять таксономії на полотні (екрані) залежить від внутрішньої організації вершин в онтографі. Текстовий опис об'єкта онтології та посилання на джерела розподілених інформаційних ресурсів відображаються поряд із зображенням та мають загальний стиль для всіх об'єктів (колір, розмір та стиль шрифту, позиція по відношенню до зображення, відповідні іконки для посилань на інформаційні ресурси різних форматів тощо) [13-14].

Згідно 3 [15-18] онтології з різними рівнями спільності (тобто онтології верхнього рівня, онтології предметної області, онтології процесів та онтології прикладних програм) можуть використовуватися для представлення архітектурних компонентів інформаційної системи управління корпоративними знаннями. Так, онтологічний інтерфейс може візуалізувати результати управління корпоративними знаннями IАC ППР ОВТ, а саме створити єдиний інформаційний простір 3 уніфікованим словником термінів ПдО для забезпечення спільного розуміння поміж експертів. В середовищі такого простору на основі концепції Semantic Web забезпечується семантична синхронізація знань, описаних в різноформатних документах і створених за різними стандартами та технологіями, що дозволяє виявити приховані взаємозв'язки причин та наслідків вирішуваних задач. За рахунок спільного розуміння концептів ПдО та семантичної зв'язності їх контекстів скорочується час на розгляд та прийняття рішення. Розширення та актуалізація онтології, що є технологічним базисом IAC управління корпоративними знаннями, не вимагає перегенерації програмного коду за рахунок ітеративної екстерналізації формальною мовою високого рівня, що значно скорочує фінансові витрати на розробку нового програмного забезпечення [13-14].

Таким чином онтологічний інтерфейс забезпечує реалізацію таких функцій:

відбір, накопичення, актуалізація інформації, проведення онтологічного та семантичного аналізу інформації, побудова тематичних глосаріїв, тезаурусів, каталогів тощо на основі виділення категоріальних рівнів мовно-онтологічних описів знань засобами онтологічного моделювання;

контекстно-орієнтована тематична класифікація та каталогізація інформації;

онтологічне управління та дослідницький інжиніринг, які забезпечують встановлення ієрархічних структур на всіх рівнях мовно-онтологічного опису знань;

формування контекстної зв'язності інформаційних масивів на основі виявлення контекстних невизначеностей;

витяг з множини текстових документів, що відображають знання, нових знань, їх системноонтологічна структуризація та формально-логічне подання у вигляді інтерактивних онтологічних документів;

агрегація та інтеграція в єдине мережецентричне онтолого-кероване середовище фізично та тематично розподілених гетерогенних інформаційних масивів різних форматів, створених за різними стандартами та технологіями;

забезпечення інтероперабельності інформації не лише на структурному та синтаксичному рівнях, а й на семантико-лінгвістичному, що забезпечує максимально повний доступ до інформації;

усунення змістових конфліктів між інформаційними одиницями та дублювання інформації;

підключення через інтерфейси інтероперабельної взаємодії користувачів до інших інформаційних систем 3 метою розширення їх можливостей на основі використання технології обміну даними 3 іншими системами;

формування онтологічних капсул знань, які включають в себе мережеве онтологічне представлення процесу вирішення конкретної задачі, семантично пов'язані мережеві інформаційні ресурси, підключені індекси додаткових інформаційних джерел за потребою, а також індекси контекстної зв'язності $з$ тематично спорідненою інформацією органів військового управління та установ, що залучаються до процесів створення ОВТ;

реалізація інтерактивної форми взаємодії з кожним документом та забезпечення його атрибутивної інтеграції з обробленими інформаційними ресурсами;

формування інтероперабельних протоколів підтримки мережецентричної взаємодії та взаємозв'язку між документами, інформаційними системами, базами даних та знань, які мають значну кількість міждисциплінарних відношень, та створені на основі використання різних інформаційних технологій і стандартів;

візуалізація інтерфейсу користувача єдиного мережецентричного інформаційного середовища, яке об'єднає інформаційні ресурси усіх залучених до процесів розробки ОВТ установ, закладів та органів військового управління Міністерства оборони України та Генерального штабу Збройних Сил України.

\section{Висновки}

Ступінь обгрунтованості рішень, що приймаються в процесі розробки (модернізації) ОВТ, визначається низкою факторів, зокрема якістю і повнотою інформації, що використовується.

Формальну концептуалізацію знань, якими оперують експерти цієї області в своїй професійній діяльності, доцільно здійснювати шляхом моделювання ПдО на основі засобів онтологічного інжинірингу, які дозволяють вирішити проблему семантичної гетерогенності. 
Взаємодія користувачів ІАС ППР ОВТ розглядається як велика онтолого-керована система, яка представляє природно-мовні об'єкти, як елементи загальної природно-мовної картини з відповідними взаємопов'язаними ПдО, що описуються онтологіями.

\section{Список літератури}

1. Комплексные инструментальные средства инженерии онтологий / В.Ю. Величко, К.С. Малахов, В.В. Семенков, А.Е. Стрижак // International Journal "Information Models and Analyses". - 2014. - Vol. 3. - No. 4. - P. $336-361$.

2. Гладун В.П. Процессы формирования новых знаний [Текст] / В.П. Гладун. - София: СД “Педагог 6”, 1994. $192 \mathrm{c}$.

3. Палагин А.В. Онтологические методы и средства обработки предметных знаний / А.В. Палагин, С.Л. Крывый, Н.Г. Петренко. - Луганск: изд-во ВНУ им. В. Даля, 2012. - 323 с.

4. Gruber T.R. A translation approach to portable ontology specifications / T.R. Gruber // Knowledge Acquisition. 1993. - Vol. 5. - P. 199-220.

5. Guarino N. Understanding, Building, and Using Ontologies [Electronic resource] / N. Guarino. - Available at: http://ksi.cpsc.ucalgary.ca/KAW/KAW96/guarino/guarino.html.

6. Головін О.О. Таксономічне відображення інформаційних ресурсів дослідно-конструкторських робіт / О.О. Головін // Озброєння та військова техніка: науково-технічний журнал. - 2019. - Вип. 4(24). С. 12-21. https://doi.org/1034169/2414-0651.2019.4(24).12-21.

7. Попова М.А. Онтологія взаємодії в середовищі геоінформаційної системи: дис. ... канд. техн. наук: 05.13 .06 інформаційні технології / Попова М.А. -- Київ: НАН України, Ін-т телекомунікацій і глоб. інформ. простору, 2014. - 240 с.

8. Головін О.О. Застосування методології трансдисциплинарних онтологій в інформаційно-аналітичній системі підтримки процесів оснащення озброєнням та військовою технікою / О.О. Головін // Системи озброєння і військова техніка. - 2019. - № 3(59). - C. 17-24. https://doi.org/10.30748/soivt.2019.59.02.

9. Овдій О.М. Онтології у контексті інтеграції інформації: представлення, методи та інструменти побудови / О.М. Овдій, Г.Ю. Проскудіна // Проблеми програмування. - 2004. - № 2-3. - С. 353-365.

10. Kashyap V. Semantic and Schematic Similarities Between Database Objects: a Context-Based Approach / V. Kashyap, A. Sheth // The VLDB Journal (The International Journal on Very Large Data Bases). - 1996. - Vol. 5, Iss. 4. - P. 276-304.

11. Klien E. Requirements for Geospatial Ontology Engineering / E. Klien, F. Probst // AGILE'05: Proc. of the 8th Conference on Geographic Information Science. - 2005. - P. 251-260.

12. Про один підхід до аналізу та розуміння природомовних об'єктів / О.В. Палагін, С.Ю. Світла, М.Г. Петренко, В.Ю. Величко // Комп’ютерні засоби, мережі та системи. - 2008. - № 7. - С. 128-137.

13. Попова М.А. Модель онтологического интерфейса агрегации информационных ресурсов и средств ГИС / М.А. Попова // International Journal "Information Technologies and Knowledge". - 2013. - Vol. 7, No. 4. - P. 362-370.

14. Попова М.А. Онтологія взаємодії в середовищі геоінформаційної системи: автореф. дис. ... канд. техн. наук: 05.13.06 - інформаційні технології / Попова М.А. - Київ: НАН України, Ін-т телекомунікацій і глоб. інформ. простору, 2014. $-20 \mathrm{c}$.

15. Gomez-Perez A. Ontological Engineering: With Examples from the Areas of Knowledge Management, e-Commerce and the Semantic Web. 2nd edition / A. Gomez-Perez, M. Fernández-López, O. Corcho. - Springer, 2007. - 505 p.

16. Gruninger M. Ontology Applications and Design / M. Gruninger, J. Lee // Communications of the ACM. - 2002. № 45(2). - P. 39-41.

17. Guarino N. Formal Ontology and Information Systems / N. Guarino. // Frontiers in Artificial Intelligence and Applications. - Amsterdam: IOS Press, 1998. - Vol. 46. - 347 p.

18. Happel H. Applications of Ontologies in Software Engineering / H. Happel, S. Seedorf // ISWC'06: Proc. of the 2006 5th International Semantic Web Conference. - 2006. - P. 5-9.

\section{References}

1. Velichko, V.Y., Malakhov, K.S., Semenkov, V.V. and Stryzhak, A.E. (2014), "Kompleksnye instrumentalnye sredstva inzhenerii ontologiy" [Complex tools for the engineering of ontologies], International Journal "Information Models and Analyses”, No. 4, pp. 336-361.

2. Hladun, V.P. (1994), "Processy formirovaniya novyh znanij” [Processes of the formation of new knowledge], Pedagog 6, Sofiya, $192 \mathrm{p}$

3. Palahyn, A.V., Kryvyj, S.L. and Petrenko, N.H. (2012), "Ontologicheskie metody i sredstva obrabotki predmetnyh znanij" [Ontological methods and means of processing subject knowledge], Izdatelstcvo VNU imeni V. Dalya, Lugansk, 323 p.

4. Gruber, T.R. (1993), A translation approach to portable ontology specifications, Knowledge Acquisition, Vol. 5, pp. 199-220.

5. Guarino, N. (1997), Understanding, building and using ontologies, available at: www.ksi.cpsc.ucalgary.ca/KAW/KAW96/guarino/guarino.html.

6. Holovin, O.O. (2019), "Taksonomichne vidobrazhennia informatsiinykh resursiv doslidno-konstruktorskykh robit" 
[Taxonomic display of information resources of research and development works], Weapons and military equipment, No. 4(24), pp. 12-21. https://doi.org/1034169/2414-0651.2019.4(24).12-21.

7. Popova, M.A. (2014), “Ontologiya vzayemodiyi v seredovishi geoinformacijnoyi sistemi” [Ontology of interaction in the middle of the geographic information system: dissertation], Kyiv, 240 p.

8. Holovin, O.O. (2019), "Zastosuvannia metodolohii transdystsyplinarnykh ontolohii v informatsiino-analitychnii systemi pidtrymky protsesiv osnashchennia ozbroienniam ta viiskovoiu tekhnikoiu" [Application of methodology of transdisciplinarity ontology in information-analytical system for support processes with equipping of armament and military equipment], Systems of Arms and Military Equipment, No. 3(59), pp. 17-24. https://doi.org/10.30748/soivt.2019.59.02.

9. Ovdii, O.M. and Proskudina, H.Yu. (2004), "Ontologii u konteksti integratsii informatsii: predstavlennia, metody ta instrumenty pobudovy" [Ontology in the context of integration of information: presentation, methods and tools to prompt], Problemy prohramuvannia, No. 2-3, pp. 353-365.

10. Kashyap, V. and Sheth, A. (1996), Semantic and Schematic Similarities Between Database Objects: a Context-Based Approach, The VLDB Journal (The International Journal on Very Large Data Bases), Vol. 5, Iss. 4, pp. 276-304.

11. Klien, E. and Probst, F. (2005), Requirements for Geospatial Ontology Engineering, AGILE'05: Proc. of the 8th Conference on Geographic Information Science, pp. 251-260.

12. Palahin, O.V., Svitla, S.Yu., Petrenko, M.H. and Velychko, V.Yu. (2008), "Pro odyn pidkhid do analizu ta rozuminnia pryrodomovnykh obiektiv" [About one an approach before the analysis and understanding of natural language areas], Kompiuterni zasoby, merezhi ta systemy, No. 7, pp. 128-137.

13. Popova, M.A. (2013), "Model' ontologicheskogo interfejsa agregacii informacionnyh resursov i sredstv GIS” [Model of the ontological interface of aggregation of information resources and GIS tools], International Journal "Information Technologies and Knowledge”, Vol. 7, No. 4, pp. 362-370.

14. Popova, M.A. (2014), "Ontologiya vzayemodiyi v seredovishi geoinformacijnoyi sistemy" [Ontology of interaction in the middle of the geographic information system: abstract of dissertation], Kyiv, $20 \mathrm{p}$.

15. Gomez-Perez, A., Fernández-López, M. and Corcho, O. (2007), Ontological Engineering: With Examples from the Areas of Knowledge Management, e-Commerce and the Semantic Web, 2nd edition, Springer, 505 p.

16. Gruninger, M. and Lee, J. (2002), Ontology Applications and Design, Communications of the ACM, No. 45(2), pp. 39-41.

17. Guarino, N. (1998), Formal Ontology and Information Systems, Frontiers in Artificial Intelligence and Applications, IOS Press, Vol. 46, Amsterdam, 347 p.

18. Happel, H. and Seedorf, S. (2006), Applications of Ontologies in Software Engineering, ISWC'06: Proc. of the 2006 5th International Semantic Web Conference, pp. 5-9.

Надійшла до редколегії 18.02.2020

Схвалена до друку 17.03.2020

Відомості про авторів:

\section{Головін Олексій Олександрович}

кандидат технічних наук

старший науковий співробітник

начальник науково-дослідного управління

Центрального науково-дослідного інституту

озброєння та військової техніки

Збройних Сил України,

Київ, Україна

https://orcid.org/0000-0003-4662-4559

\section{Попова Марина Андріївна}

кандидат технічних наук

завідувач відділу Національного центру

"Мала академія наук України",

Київ, Україна

https://orcid.org/0000-0002-0258-1713

\section{Яценко Костянтин Григорович}

кандидат технічних наук доцент

Харківського національного університету

Повітряних Сил ім. І. Кожедуба,

Харків, Україна

https://orcid.org/0000-0001-7822-8521

\section{Information about the authors:}

\section{Oleksii Holovin}

Candidate of Technical Sciences

Senior Research

Chief of the Directorate for Scientific Research

of Central Research Institute

of Armament and Military Equipment

of the Armed Forces of Ukraine,

Kyiv, Ukraine

https://orcid.org/0000-0003-4662-4559

\section{Maryna Popova}

Candidate of Technical Sciences

Head of Department of National Center

"Minor Academy of Sciences of Ukraine",

Kyiv, Ukraine

https://orcid.org/0000-0002-0258-1713

\section{Kostiantin Yatsenko}

Candidate of Technical Sciences Associate Professor

of Ivan Kozhedub Kharkiv

National Air Force University,

Kharkiv, Ukraine

https://orcid.org/0000-0001-7822-8521 


\title{
ОНТОЛОГИЧЕСКИЕ ОСНОВЫ ВЗАИМОДЕЙСТВИЯ ЕКСПЕРТОВ С ИНФОРМАЦИОННО-АНАЛИТИЧЕСКОЙ СИСТЕМОЙ ПОДДЕРЖКИ ПРИНЯТИЯ РЕШЕНИЙ ПО РАЗВИТИЮ ВООРУЖЕНИЯ И ВОЕННОЙ ТЕХНИКИ
}

\author{
А.А. Головин, М.А. Попова, К.Г. Яценко
}

Решение проблемы семантической гетерогенности данных в перспективной информационно-аналитической системе осуществляется за счет использования инструментария онтологий путем формирования из входной информации унифицированного информационно-понятийного пространства. Использование методов анализа естественноязыковых объектов и классической логики первого порядка позволяет осуществить объединение формального представления семантики с информационными массивами, которые составляют основу нарратива всей входящей информации об описании образиов ВBT.

Ключевые слова: информачионно-аналитическая система, онтология, предметная область, онтологический интерфейс, нарратив информационных ресурсов.

\section{ONTOLOGICAL PRINCIPLES FOR COOPERATION BETWEEN EXPERTS ON INFORMATION AND ANALYTICAL DECISION SUPPORT SYSTEM OF WEAPON AND MILITARY EQUIPMENT DEVELOPMENTS}

\author{
O. Holovin, M. Popova, K. Yatsenko
}

The interaction between experts and information resources within the forward-looking information and analytical decision support system for the development of weapons and military equipment is complicated weakly-formalized view data and incomplete and inaccurate descriptions of the objects to be analyzed. Solving the problem of semantic heterogeneity of data is possible through the use of tools by creating ontologies from input data unified information space through a combination of conceptual descriptions of information based on object-oriented procedures formalization of interpretational descriptions of functions that control the supply of an information resource. Application of appropriate adequate conceptual models allows to combine the formal presentation semantics embedded in ontology information files that form the basis of all narrative input information concerning descriptions of weapons and equipment. The methodology of information-analytical system are presented in an integrated set of methods for analyzing natural language objects of classical first-order logic for their formal-logical representation, structuring ontological knowledge, application processing procedures and architectures appropriate information-analytical system based on ontology, and also selecting the appropriate <method - architecture > pair. Organizing and managing a large variety of data formats, both from our own databases and from integrated sources, is carried out using ontological interface that combines the principles of ontological knowledge management concept of Semantic Web. In such an environment, the semantic synchronization of the knowledge described in different format documents created according to different standards and technologies is ensured. Due to the common understanding of domain concepts and the semantic coherence of their contexts, as well as the identification of hidden relationships between the causes and effects of the tasks being solved, the time to consider and make decisions is reduced.

Keywords: information-analytical system, ontology, subject area, ontological interface, narrative of information resources. 